\title{
IMPLEMENTASI LENSES THEORY DALAM PEMBUATAN GAME “KISAH PANJI SAKTI” BERBASIS MOBILE
}

\author{
I Kadek Dwi Yartahadi1), I Made Ardwi Pradnyana2), I Made Putrama3). \\ 1 Fakultas Teknik dan Kejuruan, Universitas Pendidikan Ganesha \\ Email: dwiyartahadi@gmail.com, ardwi.pradnyana@undiksha.ac.id, made.putrama@undiksha.ac.id
}

\begin{abstract}
ABSTRAK
Penelitian ini bertujuan: (1) Untuk pengembangan Lenses Theory dalam Pembuatan Game "Kisah Panji Sakti" Berbasis Mobile. (2) Untuk mengetahui respon masyarakat terhadap Implementasi Lenses Theory dalam Pembuatan Game "Kisah Panji Sakti" Berbasis Mobile. Metode penelitian yang digunakan adalah penelitian dan pengembangan. Game "Kisah Panji Sakti" Berbasis Mobile ini dikembangkan menggunakan model GDLC. Subyek penelitian adalah generasi muda rentang umur 12 hingga 35 tahun dengan menggunakan angket. Data yang dikumpulkan dianalisi secara deskriptif. Data dikumpulkan dengan cara uji whitebox, uji blak box, uji ahli media, uji usability dan respon pengguna. Analisis data dalam penilitian ini berdasarkan buku The Art of Game Design_A Book of Lenses. Hasil penelitian ini adalah aplikasi diimplementasikan menggunakan bahasa pemrograman C\# dengan editor Unity. Seluruh fitur yang terdapat pada Game "Kisah Panji Sakti" Berbasis Mobile ini sudah berjalan dengan baik. Respon pengguna terhadap Game "Kisah Panji Sakti" Berbasis Mobile menggunakan perhitungan skala likert, peneliti mendapatkan hasil persentase sebanyak $89.44 \%$ yang berarti hasil respon dalam rentangan sangat baik.
\end{abstract}

Kata kunci: Game adventure, gdlc, kisah panji sakti, lenses theri desain game unity.

\section{ABSTRACT}

This study aims: (1) for the development of Theory Lenses in Making the Game "The Story of Panji Sakti" Based on Mobile. (2) To find out the public response to the Implementation of Theory Lenses in Making the Game "The Story of Panji Sakti" Based on Mobile. The research method used is research and development. This Mobile Based Game "Panji Sakti Story" was developed using the GDLC model. The research subjects were young people aged 12 to 35 years using a questionnaire. The collected data is analyzed descriptively. Data was collected using Whitebox test, black box test, media expert test, usability test, and user response. Data analysis in this study is based on the art of game design book of lenses. The results of this study are that the application is implemented using the $C$ \# programming language with the editor of Unity. All the features contained in the Mobile Based Game "The Story of Panji Sakti" have gone well. The user's response to the Mobile Based Game of "Panji Sakti Story" uses a Likert scale calculation, the researcher gets a percentage result of $89.44 \%$, which means that the response results in a very good range.

Keywords : Adventure games, gdlc, the story of panji sakti, Lenses Theory desain game, unity.

\section{PENDAHULUAN}

Bali merupakan salah satu dari sekian banyaknya pulau di Indonesia yang terkenal hingga ke mancanegara. Salah satu dari bagian kebudayaan Bali adalah cerita rakyat. Panji Sakti [14], merupakan anak dari seorang raja Sri Aji Dalem Sagening dengan abdi raja yang bernama Si Luh Pasek Panji.

Game berasal dari bahasa inggris yang berarti permainan, game telah menjadi satu hal yang ada di dalam keseharian pemain. Dimainkan dengan aturan-aturan tertentu. Ketika memulai sebuah permainan tentunya ada yang menang dan ada yang kalah. Perkembangan game platform juga dapat dilihat secara langsung oleh masyarakat, pada mulanya game hanya dimainkan di komputer dan console tetapi sekarang sudah memasuki era mobile game[2]. Mobile game telah dibuat di berbagai macam platform seperti Symbian, Apple IOS, Android serta Windows Phone. 
Permainan yang menggunakan media elektronik, yang dibuat dengan teknik dan metode tertentu yang mempunyai potensi yang sangat besar dalam membangun motivasi mencapai tujuan. Terdapat beberapa kriteria yang harus diperhatikan untuk mengembangkan game dengan kualitas yang baik. Kriteria tersebut [2], functional game yang artinya fitur dan operasional yang dimiliki game tersebut. Selanjutnya yaitu internally complete, kriteria ini mencakup mengenai aturan, cabang, dan kondisi yang ada pada game. Balanced, menunjukkan kesulitan dari suatu permainan, game tidak terlalu sulit dan game tidak terlalu mudah. Fun merupakan dalam sebuah permainan harus bisa menarik, menghibur, menantang, dan membuat pemain ingin memainkannya kembali. Kriteria terakhir yaitu Accessible dalam permainan harus mudah digunakan dan dipahami oleh semua pengguna dan terdapat beberapa sudut pandang yang dapat digunakan untuk merancang sebuah game yang baik. Kemudian untuk rumusan masalah peneliti menemukan dua permasalahan yaitu, (1) bagaimana Implementasi lenses theory dalama pembuatan game "Kisah Panji Sakti" berbasis mobile?, (2) bagaimana respons pengguna terhadap Implementasi lenses theory dalam pembuatan game "Kisah Panji Sakti" berbasis mobile?

Pemecahan masalah yang digunakan oleh peneliti adalah menggunakan metode GDLC dengan bantuan lenses theory desain game menurut buku [1], The art of game design_a book of lenses, sehingga hasil yang di dapatkan berdasarkan lenses theory ini menjadi lebih memuaskan.

Adapun tujuan yang diharapkan dapat dicapai dari dikembangkannya aplikasi game "Kisah Panji Sakti" berbasis mobile adalah sebagai berikut, (1) untuk pengembangan lenses theory dalam pembuatan game "Kisah Panji Sakti" berbasis mobile, (2) untuk mengetahui responss masyarakat terhadap Implementasi lenses theory dalam pembuatan game "Kisah Panji Sakti" berbasis mobile, kemudian untuk pengembang game selanjutnya dalam pembuatan game bisa berpatokan pada lenses theory game yang terdapat pada buku [1], the art of game design_ a book of lenses, atau bisa dari sumber yang lain. Dalam pengembangan game "Kisah Panji Sakti" ini dapat kembali menyampaikan nilai-nilai luhur dan budaya cerita rakyat pada masyarakat yang kini sudah mulai ditinggalkan

\section{METODE}

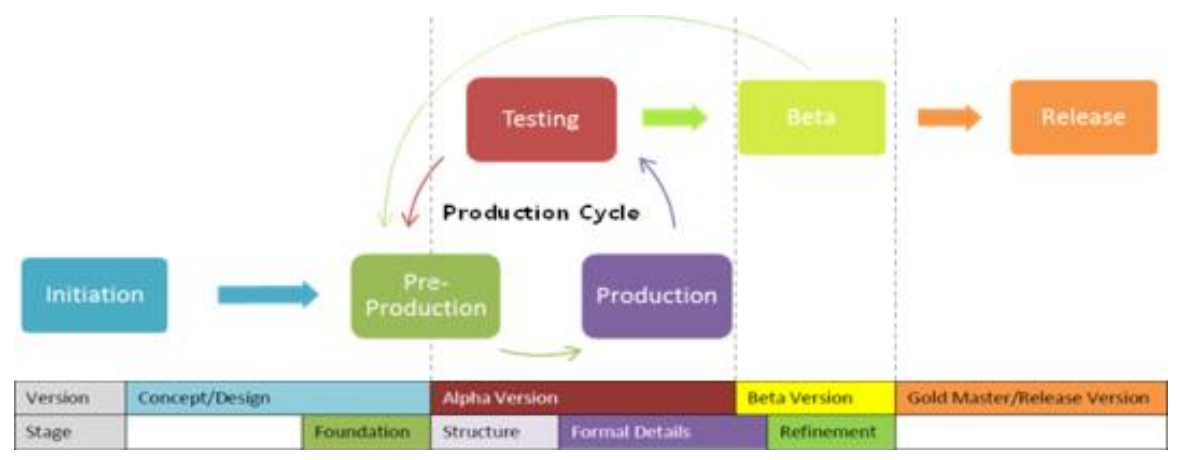

Gambar 1.Skema metode GDLC

Metode yang digunakan dalam penilitian ini adalah metode GDLC (Game Development Life Cycle) [7], dalam pengembangan game cerita rakyat "Kisah Panji Sakti" berbasis mobile, metode GDLC terdiri dari enam tahap, keenam tahap tersebut adalah Initiation, Pre-Production, Production, Testing, Beta dan Release. (1) Initiation merupakan tahap pertama yang dilakukan dalam menciptakan sebuah game, dengan menciptakan konsep kasar seperti apa game yang akan dibuat serta gagasan dan konsep dari game tersebut, kemudian sumber data dalam penelitian ini berasar dari penelitian yang sudah pernah dilakukan (Adi Darma 2017) dan analisis data dalam penelitian ini berdasarkan lenses theory. Data yang didapat nantinya akan dianalisis untuk kebutuhan pengembangan aplikasi. (2) Pre-production adalah salah satu tahap pertama dan terpenting dari production cycle. Pada tahap pre-production ini melibatkan penciptaan dan revisi design game dan pembuatan prototype game. (3) Prodution adalah tahap inti yang berkisar pada penciptaan asset, pembuatan source code dan integrasi kedua elemen tersebut. Dalam tahap pre-production, sebelumnya telah disusun kerangka game. (4) Testing adalah tahap dimana aplikasi telah siap untuk diperkenalkan dan dilakukan pengujian kelayakan. Pengujian dalam konteks ini berarti pengujian internal untuk menguji usability dan playability. Pengujian ini dilakukan dengan tujuan untuk memastikan game yang telah dibangun berdasarkan rancangan yang dibuat, sudah benar dan setiap 
fungsi yang terdapat pada game dapat berjalan dengan baik. (5) Beta adalah tahap dimana aplikasi game Implementasi lenses theory dalama pembuatan game "Kisah Panji Sakti" berbasis mobile, dilakukan pengujian pihak ketiga atau eksternal. Prototipe terkait dalam pengujian beta adalah rincian formal dan penyempurnaan. Ada beberapa pengujian yang dilakukan pada tahap ini, diantaranya yaitu uji blackbox, uji ahli media, dan uji respons pengguna data yang dikumpulkan dengan cara, menyebarkan angket dari berbagai kalangan di mulai dari usia 12 sampai 35 tahun, uji respons pengguna menggunakan skala likert dan untuk uji blackbox, ahli media menggunakan rumus Gregory. (6) release pada tahap yang terakhir ini, produk game atau aplikasi yang dikembangkan sudah siap untuk dilepas atau diperkenalkan ke public secara umum.

\section{HASIL DAN PEMBAHASAN}

Hasil penelitian ini mencakup (1) Implementasi lenses theory dalam pembuatan game "Kisah Panji Sakti" berbasis mobile dan (2) Respons pengguna terhadap implementasi lenses theory dalam pembuatan game "Kisah Panji Sakti" berbasis mobile. Berikut uraian hasil penelitian yang lebih rinci.

\section{Hasil Tahap Initiation}

Pada tahap ini dilakukan pencarian referensi mengenai teori-teori terkait yang diperlukan dan bagaimana menerapkannya dalam pengembangan sebuah aplikasi game. Pada tahap analisis pengembangan melakukan analisis permasalahan yang terdapat pada game "Kisah Panji Sakti" yang menceritakan mengenai panji sakti [8] yang merupakan anak dari seorang raja sri aji dalem sagening dengan abdi raja yang bernama si luh pasek panji. Berdasarkan analisis yang dilakukan, penelitian sebelumnya telah menerapkan 9 lenses theory berdasakan buku berjudul [1], the art of game design a book of lenses tersebut diantaranya;

Tabel 1. Bagian Game "Kisah Panji Sakti" [10]

\begin{tabular}{|c|c|c|}
\hline$\overline{\text { NO }}$ & $\begin{array}{l}\text { BAGIAN GAME PANJI } \\
\text { SAKTI }\end{array}$ & $\begin{array}{l}\text { ANALISIS GAME "KISAH PANJI SAKTI" BERDASARKAN } \\
\text { LENSES THEORY PADA DESAIN GAME }\end{array}$ \\
\hline 1 & Stage 1 sampai stage 2 & Lenses Theory no 3,32,33,59, dan 76 \\
\hline 2 & Stage 3 & Lenses Theory no 3,7,32,33,47,59,76 dar \\
\hline 3 & Stage 4 sampai stage 9 & Lenses Theory no $3,7,32,33,47,59,64,76$ dan 78 \\
\hline
\end{tabular}

a. Kebutuhan Perangkat Lunak

Berdasarkan analisis terhadap Implementasi lenses theory dalam pembuatan game "Kisah Panji Sakti" berbasis mobile, terdapat proses-proses yang akan diimplementasikan pada game ini yakni sebagai berikut;

1. Kebutuhan Fungsional

- Pengguna mampu melihat urutan dan peringkat game di papan skor aplikasi yang pilihan tombol terdapat pada tampilan utama game.

- Pengguna mampu mengakses shop dan membeli item yang nantinya digunakan untuk memperlancar melawan musuh yang terdapat pada game.

- Pengguna mampu melihat hasil akhir permainan yang di dapat pada akhir stage.

\section{Kebutuhan Non Fungsional}

- Usability merupakan Aplikasi dapat digunakan dengan mudah, dengan struktur yang dirancang seperti game pada umumnya dan juga dengan menu - menu / pilihan yang sudah ditetapkan oleh penelit

- Portability merupakan sebuah Implementasi lenses theory dalam pembuatan game 2D "Kisah Panji Sakti" berbasis mobile ini dapat berjalan di sistem operasi Android minimal versi 4.4 (Kitkat)

- Game cerita rakyat "Kisah Panji Sakti" ini dirancang dengan button yang dapat mempermudah pengguna dalam pengoprasianya.

\section{Hasil Tahap Pre-Production}

Pada tahap ini dirancang game design dan prototype meliputi game description, game leveling, game rules, victory condition dan lost condition.

a) Model Fungsional Perangkat Lunak 
Pada tahap game levelling peneliti mengimplementasi lenses theory dalam pembuatan game "Kisah Panji Sakti" berbasis mobile ini dibuat memiliki 9 stage, pada setiap stage memiliki level atau tingkatan kesukaran masing-masing, ciri-ciri perbedaan pada masing-masing stage. Game rule yang di buat peneliti berdasarkan lenses theory desain game menurut buku [1], The art of game design_a book of lenses dimana disana dijelaskan terdapat 112 lenses theory desain game untuk membuat game yang baik berdasarkan lenses theory desain game tersebut peneliti menerpatkan beberapa kelompok di antaranya;

Tabel 2. Kategori Dalam Lenses Theory

\begin{tabular}{c|ll}
\hline NO & BAGIAN GAME PANJI & $\begin{array}{l}\text { ANALISIS GAME “KISAH PANJI SAKTI" BERDASARKAN } \\
\text { SENSES THEORY PADA DESAIN GAME }\end{array}$ \\
\hline 1 & EAKOsi Pengguna & $1,5,6,12,17,20,35,69,70,71,94,95,100,106$ \\
2 & Pengalaman Pengguna & $2,13,24,30,37,38,39,40,56,65,68,72,77,79,83,110$ \\
3 & Penghargaan & $4,25,46,47,63,80$ \\
4 & Tujuan dan peraturan & $8,9,10,14,21,32,33,34$ \\
& Game & \\
5 & Karakteristik Game & $18,27,28,29,48,49,52,53,75,92,93,99$ \\
6 & Perspektif Pengguna & $19,22,23,54,55,81$, \\
7 & Keterampilan Pemain & $31,36,41,42,57,58,74$ \\
8 & Komunitas Game & $43,44,45,96,97,98$ \\
9 & Karakter Game & $50,82,85,86,87,88,89,90,91$ \\
10 & Tampilan Permainan & $3,7,51,59,60,61,62,64,66,67$ \\
11 & Jalan Cerita dan Tema & $11,26,73,76,78,84$ \\
& Permainan & \\
12 & Pengujian dan Pemasaran & $15,16,101,102,103,104,105,107,108,109,111,112,113$ \\
& Game &
\end{tabular}

b) Victory Condition dan Lost Condition

Dalam game "Kisah Panji Sakti", victory conditionnya adalah ketika pemain berhasil melewati rintangan, membunuh prajurut dan dapat mengalahkan raja pada akhir stage tanpa kehabisan nyawa. Lost Condition pada game "Kisah Panji Sakti", pemain dinyatakan lost apabila tersentuh rintangan, terkena serangan prajurut, serangan raja sehingga persediaan nyawa habis.

\section{c) Use Case Diagram}

Untuk mengenal proses utama suatu sistem digunakan use case diagram [9]. Use Case Diagram adalah sebuah kegiatan yang dilakukan oleh sistem biasanya dalam menanggapi permintan dari pengguna.

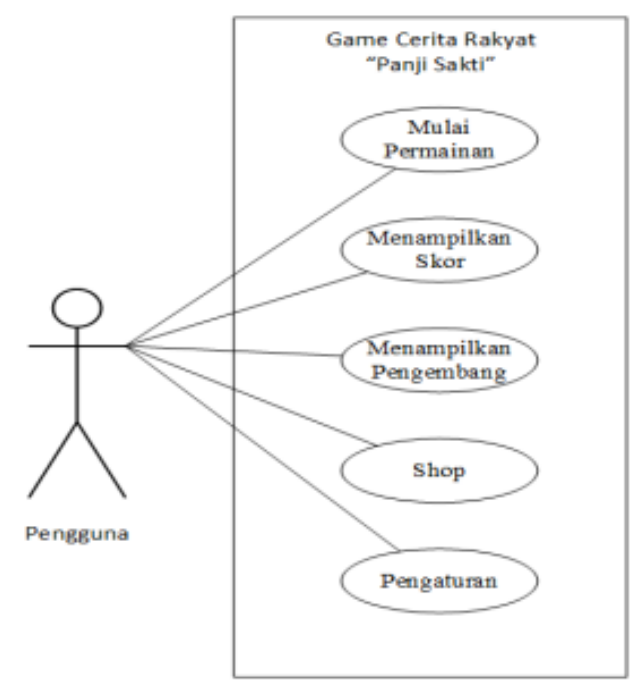

Gambar 2. Use Case Diagram Game Kisah Panji Sakti

d) Perancangan Struktur Navigasi 
Struktur navigasi dari aplikasi Implementasi lenses theory dalam pembuatan game "Kisah Panji Sakti" berbasis mobile dapat dilihat pada tampilan dibawah;

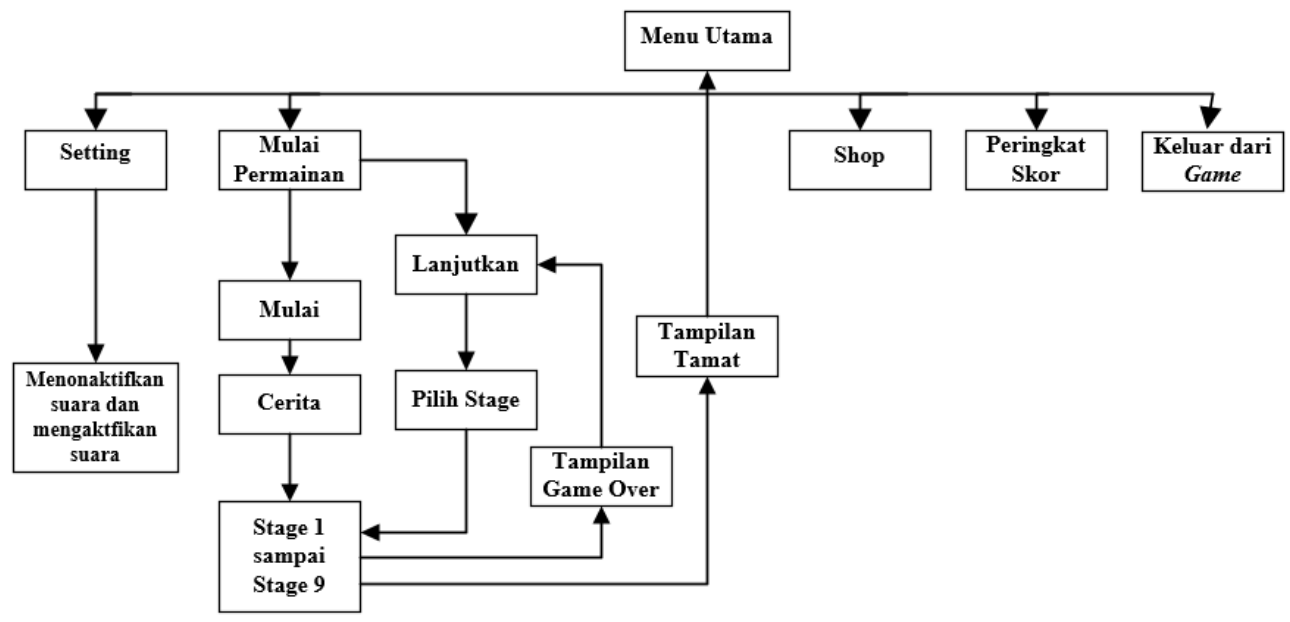

Gambar 3. Struktur Navigasi

Secara umum Implementasi Lenses Theory Dalam Pembuatan Game "Kisah Panji Sakti" Berbasis Mobile yang akan dikembangkan memiliki 4 menu utama yaitu: Mulai Permainan, Lanjutkan Permainan, Shop, dan Papan Skor. Berikut penjelasan dari masing - masing menu tersebut.

e) Perancangan Perangkat Lunak

Dengan melihat permasalahan yang terjadi maka dapat dibuat suatu game sesuai batasan masalah, pada game cerita rakyat Bali "Kisah Panji Sakti" berbasis mobile ini dirancang dengan visual 2 dimensi. Game ini hanya ini hanya dirancang untuk dimainkan single player dan di implementasikan menurut buku [1], yang di kelompokan menjadi beberapa pengelompokan menurut lenses theory desain game, pada tabel 1 ditampilkan tambahan lenses theory yang di terapkan peneliti pada game "Kisah Panji Sakti" ;

Tabel 3. Lenses Theory Tambahan Pada Game "Kisah Panji Sakti"

\begin{tabular}{l|ll}
\hline No & Bagian Game Panji Sakti & $\begin{array}{l}\text { Penerapan Lenses Theory Desain Game pada Game } \\
\text { "Kisah Panji Sakti" }\end{array}$ \\
\hline 1 & Stage 1 & Lenses Theory no 27, 25, 4 \\
2 & Stage 2 sampai stage 5 & Lenses Theory no 38, 25, 4 \\
3 & Stage 6 & Lenses Theory no 25, 4 \\
4 & Stage 7 & Lenses Theory no 74, 25, 4 \\
5 & Stage 8 sampai stage 9 & Lenses Theory no 25, 4
\end{tabular}

f) Perancangan Karakter Game

Dalam pengembangan aplikasi terdapat beberapa karakter yang akan ditampilkan. Berikut merupakan hasil dari karakter pada pre-production yang nantinya akan dikendalikan oleh pengguna dan karakter yang akan menjadi musuh. Beberapa karakter tersebut yaitu;

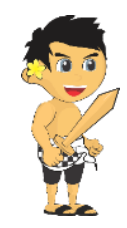

Gambar 4. Panji Sakti Kecil[10]

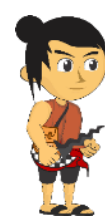

Gambar 5. Panji Sakti Dewasa[10] 


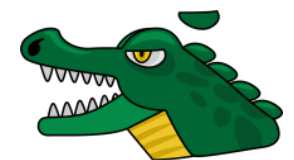

Gambar 6. Karakter Buaya (Versi Baru)



Gambar 7. Karakter Ki Pungakan Gendis (Versi Varu)

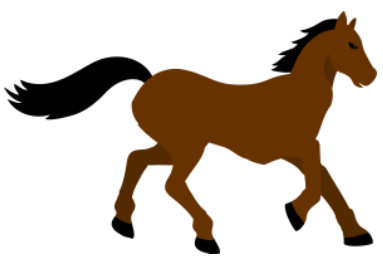

Gambar 8. Karakter Kuda (Versi Baru)

g) Perancangan Antarmuka Perangkat Lunak

Perancangan antarmuka perangkat lunak merupakan proses membangun antarmuka aplikasi yang akan digunakan untuk berinteraksi antara pengguna dengan perangkat lunak. Rancangan yang dibuat bersifat pengguna friendly [5], dimana bertujuan agar pengguna merasa tertarik, nyaman, dan mudah dalam memainkannya

Rancangan antarmuka merupakan gambaran dari rencana antarmuka yang akan diimplementasikan dalam Aplikasi Implementasi lenses theory dalam pembuatan game "Kisah Panji Sakti" berbasis mobile, berikut merupakan rancangan antarmuka game.

1) Antarmuka Tambahan Tampilan Shop

The lens of economy [1], pada fitur ini peneliti menambahkan shop. Shop membantu pemain untuk memanfaatkan koin yang sudah dikumpulkan dalam permainan.

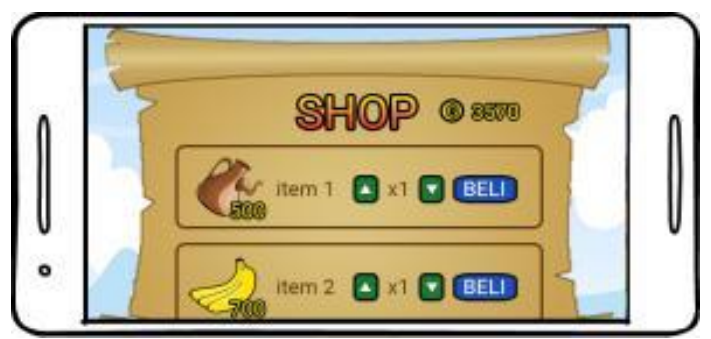

Gambar 9. Antarmuka Tambahan Shop 'The Lens of Economy' (Versi Baru)

2) Antarmuka Tambahan Stage 1

The lens of time [1], peneliti menambahkan fitur batas waktu di salah satu stage yang ada dalam Game.



Gambar 10. Antarmuka Tambahan Stage 1 'The Lens of Time' (Versi Baru) 
3) Antarmuka Tambahan Stage 3

The lens of challenge [1], peneliti Game menambah fitur tantangan baru yaitu melawan buaya.

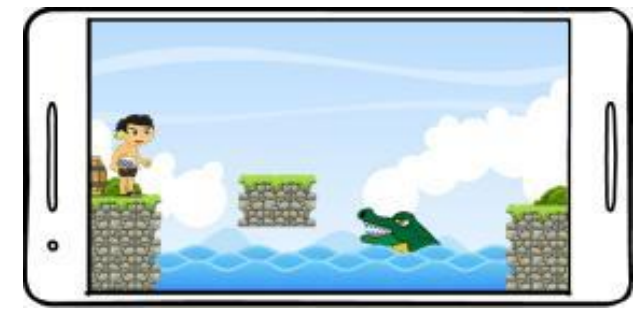

Gambar 11. Antarmuka Tambahan Stage 3 'The Lens Of Challenge' (Versi Baru)

4) Antarmuka Tambahan Stage 7

The lens of obstacle [1], Maka dari itu peneliti menambahkan sebuah fitur berupa hambatan baru.

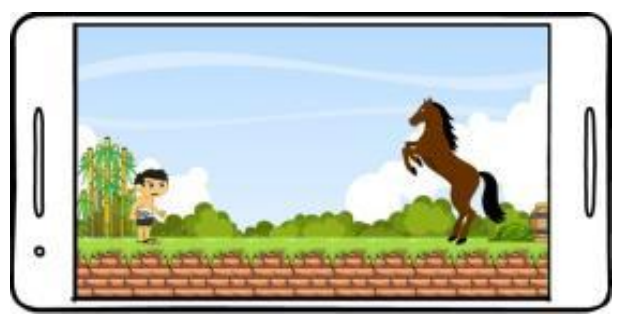

Gambar 12. Antarmuka Tambahan Stage 7 'The Lens of Obstacle' (Versi Baru)

5) Antarmuka Tambahan Skor Permainan

The lens of competition [1], tiap permainan harus dapat menentukan pemain terbaik dalam sebuah Game yang ada, dengan menambahkan papan skor.

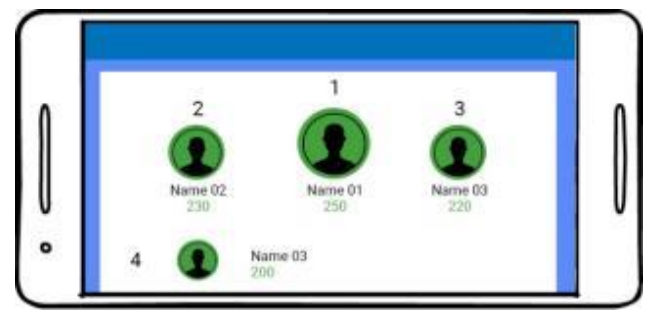

Gambar 13. Antarmuka Tambahan 'The Lens of Comepetition' (Versi Baru)

6) Antarmuka Tambahan Rintangan Pada Stage Game

The lens of flow [1], perancang game akan membuat pemain tidak menyelesaikan tujuan utama dari game, dengan menambahkan Monster.

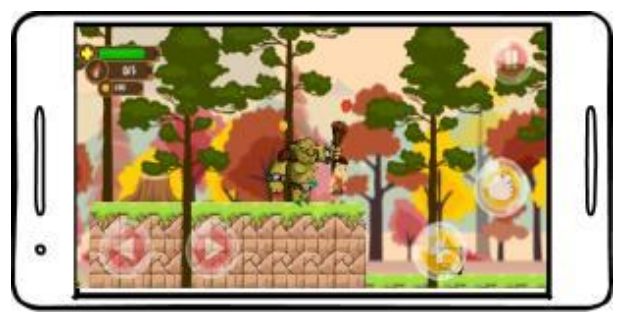

Gambar 14. Antarmuka Tambahan 'The Lens of Flow' (Versi Baru) 
7) Antarmuka Penilaian

The lens of judgment [1], maka dari itu peneliti menambahkan fitur penilaian untuk menilai pemain. penilaian ini berupa bintang yang di dapat pemain di akhir permainan.

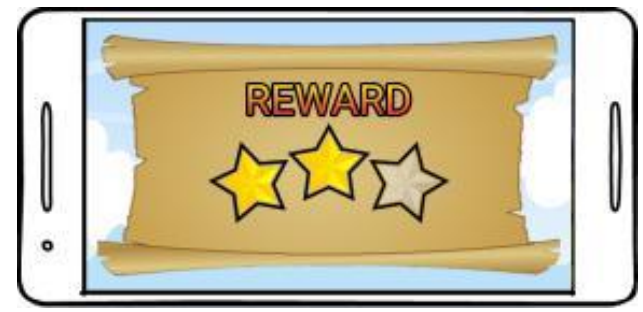

Gambar 15. Antamuka Tambahan 'The Lens of Judgment' (Versi Baru)

8) Antarmuka Kejutan

The lens of surprise [1], Maka dari itu perancang dapat menambah fitur berupa peti yang ada di dalam stage dan ketika pemain menemukannya maka pemain akan mendapat kejutan berupa bonus.

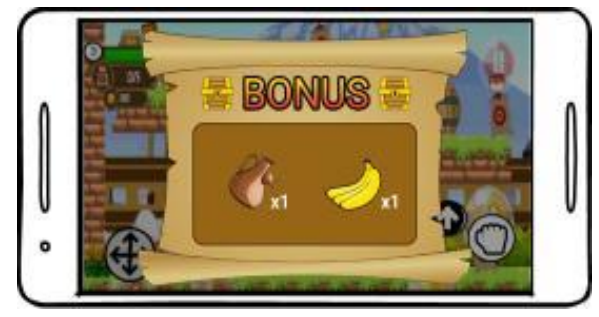

Gambar 16. Antarmuka Tambahan 'The Lens of Surprice' (Versi Baru)

\section{Hasil Tahap Production}

Tahap inti yang berkisar pada penciptaan asset, pembuatan source code dan integrasi kedua elemen tersebut. Dalam tahap pre-production, sebelumnya telah disusun kerangka game. Dalam tahap production ini [7], kerangka yang masih konseptual tersebut direalisasikan menjadi produk yang siap di testing. Rancangan antarmuka yang dibuat bersifat pengguna friendly, dimana rancangan ini bertujuan agar pengguna merasa tertarik, nyaman, dan mudah dalam memainkannya, berikut merupakan rancangan antarmuka berdasarkan lenses theory dalam game "Kisah Panji Sakti".

\section{a) Hasil Layar Antarmuka}

Hasil layar antarmuka dilakukan berdasarkan rancangan antarmuka yang telah dilakukan. Kesesuaian rancangan dan implementasi antarmuka ditunjukkan pada gambar dibawah ini.

1) Layar Antarmuka Barter

Berikut merupakan hasil dari rancangan game berdasarkan lenses theory [1], no 52 the lens of economy, peneliti menambahkan pilihan barter pada game supaya pemain bisa memanfaatkan prolehan poin, bintang dan mas dalam game "Kisah Panji Sakti".

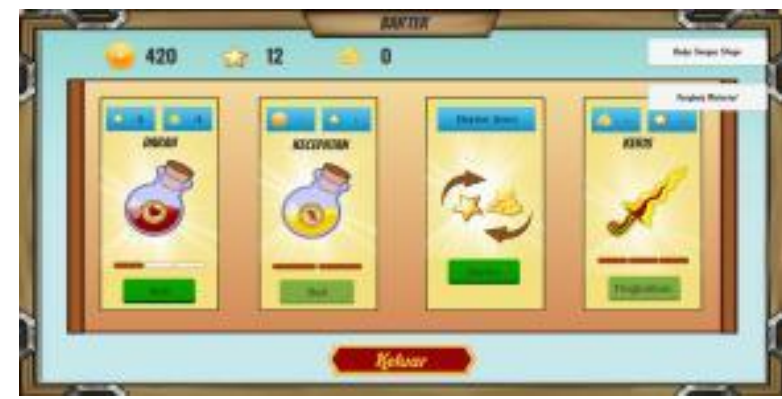

Gambar 17. Hasil Antarmuka Barter (Versi Baru) 
2) Layar Antarmuka Skor Permainan

pada tampilan dibawah ini peneliti menambahkan papan skor supaya pemain mampu berkompetisi berdasarkan lenses theory [1], no 43 the lens of competition.

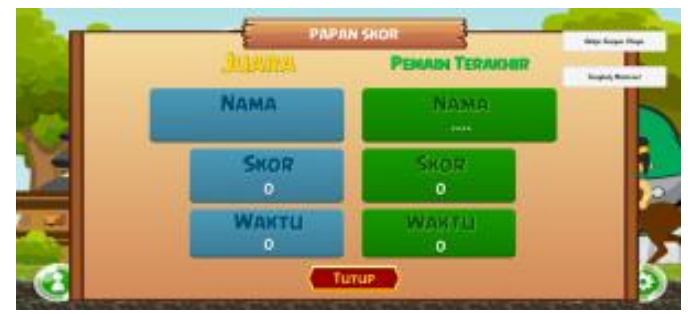

Gambar 18. Hasil Antarmuka Skor Permaian (Versi Baru)

3) Layar Antarmuka Stage Selesai

Berdasarkan gambar dibawah [1], peneliti menambahkan prolehan hasil pada setiap akhir stage berdasarkan the lens of judgment.

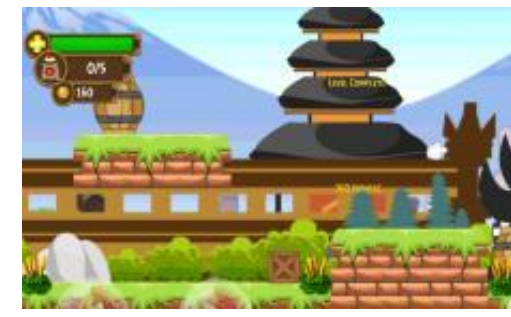

Gambar 19. Hasil Antarmuka [10]

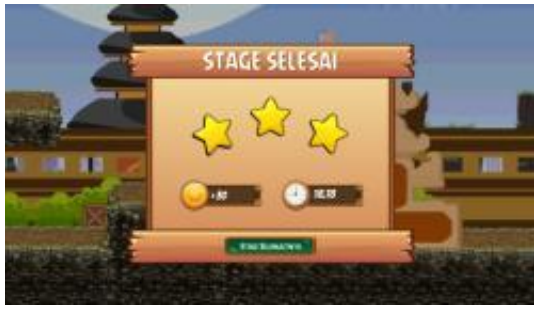

Gambar 20. Hasil Antarmuka (Versi Baru)

4) Layar Antarmuka Stage 3

Berdasarkan lenses theory [1], no 38 the lens of challenge sebelum dan sesudah tampilan di sesuaikan dengan teori pada game, peneliti menambahkan rintangan tambahan yaitu buaya.



Gambar 21. Hasil Antarmuka Stage 3 [10]

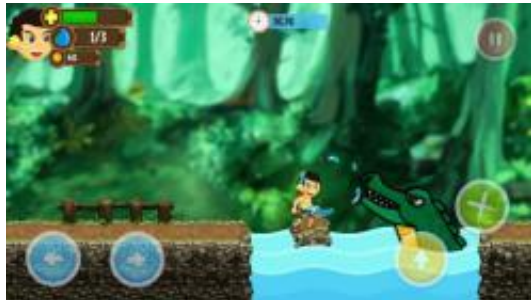

Gambar 22. Hasil Antarmuka Stage 3 (Versi Baru)

5) Layar Antarmuka Stage 7

Berdasarkan gambar dibawah peneliti menambahkan karakter kuda dan raja sebagai lawan dari panji sakti berdarsarkan lenses theory [1], no 74 the lens of obstacle.

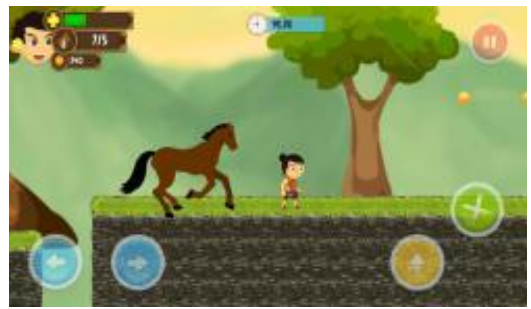

Gambar 23. Hasil Antarmuka Stage 7 [10]

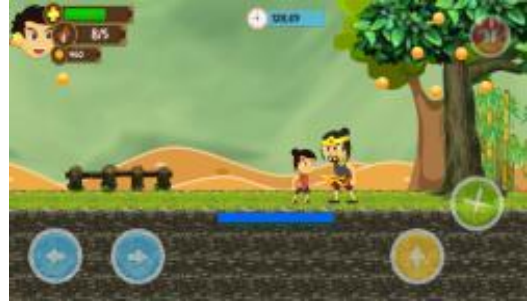

Gambar 24. Hasil Antarmuka Stage 7 (Versi Baru) 


\section{Testing}

Tahap Testing adalah tahap dimana aplikasi telah siap untuk diperkenalkan dan dilakukan pengujian kelayakan. Pengujian dalam konteks ini berarti pengujian internal untuk menguji usability dan playability. Pengujian yang dilakukan dengan uji whitebox.

Pengujian whitebox merupakan metode desain test case yang menggunakan struktur kontrol dari desain prosedural untuk memperoleh test case. Uji whitebox menggunakan struktur data internal untuk menjamin validitasnya [10]. Pada pengujian whitebox ini dilakukan oleh pengembang sendiri dan bebrapa orang dibidangnya.

\section{Beta}

Tahap Beta adalah tahap dimana aplikasi dilakukan pengujian pihak ketiga atau eksternal. Pengujian beta menggunakan pengujian blackbox, karena prototipe terkait dalam pengujian beta adalah rincian formal dan penyempurnaan. Pada tahap uji coba ini dilakukan oleh dua orang penguji aplikasi game "Kisah Panji Sakti" berbasis mobile yang di terapkan pada perangkat android yang berbeda. Berikut gambaran grafik penggunaan aplikasi pada perangkat android yang berbeda. Hasil pengujian menyatakan bahwa game dapat berjalan pada kedua tipe perangkat android yang digunakan.

\section{a) Uji Ahli Media}

Pada saat uji ahli media peneliti menggunakan uji Gregory dengan melibatkan dua orang ahli yang merupakan dosen di jurusan pendidikan teknik informatika universitas pendidikan ganesha, hasil penilaian dari dua dosen 29 jawaban dinyatakan relevan jadi koefisien validitas isi instrument yang diuji coba adalah 0,72 yang berkategori tinggi, untuk instrument yang dinilai tidak relevan telah diperbaiki sehingga semua instrument dapat di ujicoba.

\section{b) Uji Respons pengguna}

Uji respons pengguna yang di lakukan oleh peneliti yang didapat dari 15 responsden yang terdiri dari usia 12-35 tahun.

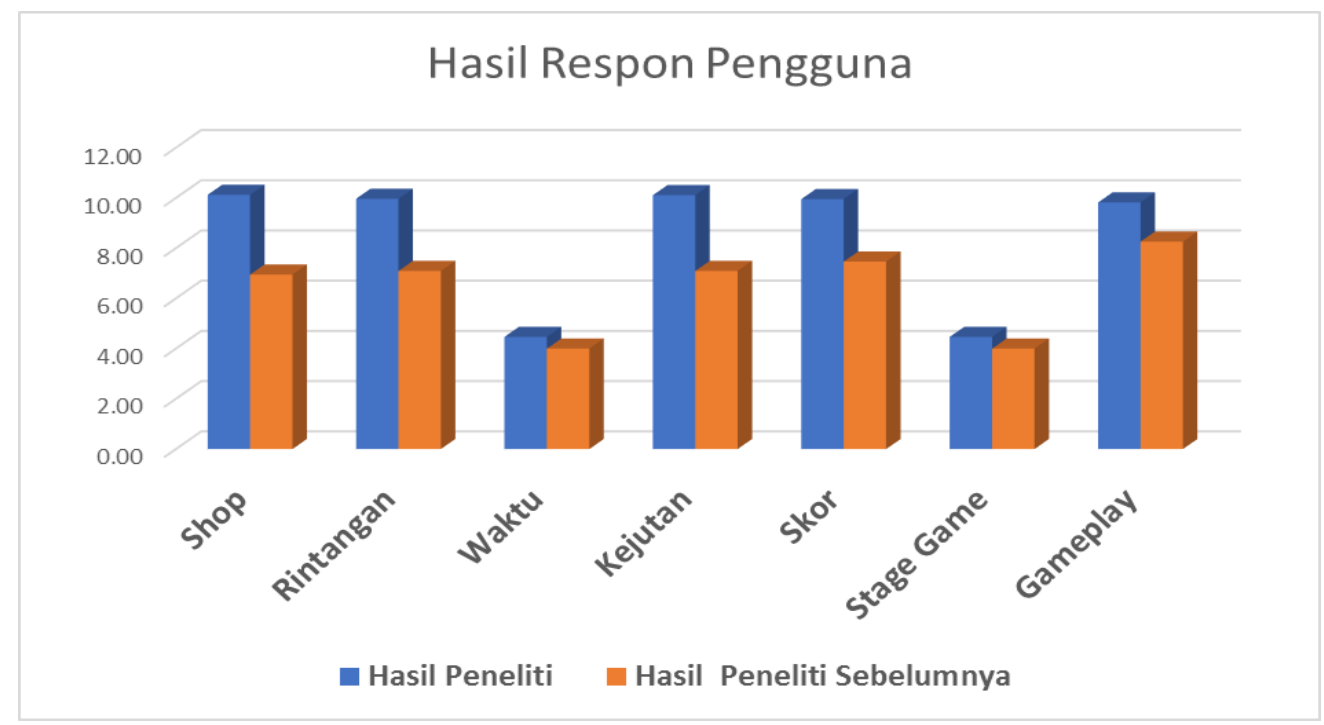

Gambar 25. Data Hasil Respons Pengguna

Dari grafik di atas dapat dilihat bahwa, terdapat 7 kategori yang digunakan untuk menggetahui bagaimana respon pengguna terhadap permainan game "kisah panji sakti" 7 kategori tersebut adalah barter, rintangan, waktu, kejutan, skor, stage game dan yang terakhir gameplay. Dalam respon pengguna peneliti mendapatkan skor lebih tinggi dari peneliti sebelumnya yakni dengan rata-rata $8.42 \%$ sedangkan peneliti sebelumnya mendapat hasil dengan rata-rata $6.41 \%$. Berdasarkan hasil yang didapatkan dalam grafik di atas, terdapat peningkatan hasil respon pengguna berdasarkan perhitungan rata-rata yang dibuat oleh peneliti. Berikut merupakan tabel hasil dari penelitian peneliti 
dengan judul game "Kisah Panji Sakti" berbasi mobile, yang menunjukkan bahwa hasil lebih baik dari penelitian sebelumnya.

Tabel 4.Hasil Peningkatan pada game "Kisah Panji Sakti"

\begin{tabular}{c|cc}
\hline No & Kategori & Hasil \\
\hline 1 & Barter & $3.18 \%$ \\
2 & Rintangan & $2.18 \%$ \\
3 & Waktu & $0.47 \%$ \\
4 & Kejutan & $3.02 \%$ \\
5 & Skor & $2.49 \%$ \\
6 & Stage Game & $0.47 \%$ \\
7 & Gameplay & $1.56 \%$ \\
\hline
\end{tabular}

Menurut [11], dapat difungsikan sebagai media untuk menyampaikan kekayaan Budaya Indonesia kepada generasi yang lebih muda, berdasarkan pemaparan tersebut penulis merasa tujuan utama dalam pembuatan game ini telah terpenuhi. Pada penelitian ini digunakan skala likert [12], berikut pembobotan dan perhitungannya.

Tahap keenam adalah release, tahap akhir dari metode GDLC[7], produk game yang dibuat sudah dalam bentuk apk dan sudah siap untuk disebarluaskan ke kalangan umum. Pada tahap ini dilakukan pembuatan dokumentasi dari game mulai dari cara memasang game sampai dengan cara penggunaan game.

Berdasarkan hasil dari penelitian game "Kisah Panji Sakti" dengan penelitian terkait didapatkan hasil bahwa [7], metode GDLC (Game Development Life Cycle) sangat cocok digunakan dalam pengembangan game karena tahapan-tahapan dari metode tersebut sangat sesuai dengan karakteristik dari pengembangan game. Penggunaan Lenses Theory dalam mengembangan game dirasa sangat bermanfaat karena dapat memetakan pengembangan dengan maksimal mulai dari tahap awal menentukan ide, perancangan game sampai dengan pengujian dan pemasaran game. Hasil dari penerapan [7], metode GDLC dan lenses theory [1], menghasilkan game "Kisah Panji Sakti" dengan kategori persentase nilai sangat baik atau sangat sesuai.

\section{SIMPULAN DAN SARAN}

Simpulan dan saran tersebut adalah sebagai berikut. Implementasi lenses theory dalam pembuatan game "Kisah Panji Sakti" berbasis mobile ini merupakan aplikasi permainan yang di dalamnya terdapat nilai atau materi tentang kisah cerita rakyat bali. secara umum implementasi lenses theory dalam pembuatan game "Kisah Panji Sakti" berbasis mobile yang akan dikembangkan memiliki 4 menu utama yaitu: permainan baru, lanjutkan permainan, barter dan papan skor perancangan game "kisah panji sakti" telah berhasil dirancang dengan menggunakan model fungsional berupa UML (Unified Modeling Language) [10] yaitu dengan menggunakan use case diagram dan activity diagram.

Game "Kisah Panji Sakti" diimplementasikan menggunakan bahasa pemrograman C\# dengan editor unity. Hasil pengujian yang sudah dilakukan, masuk dalam rentangan sangat baik dilihat dari hasil pengujian uji ahli media presentase hasil uji ahli media berdasarkan tabel 4.6. Kriteria tingkat validitas isi, nilai 0,72 berada pada tingkat validitas "Tinggi". Dengan kata lain, game "Kisah Panji Sakti" berbasis mobile ini telah memenuhi aspek media pada game dan layak untuk dimainkan dikalangan masyarakat khususnya generasi muda [13], dengan aspek uji respons pengguna dengan mendapatkan persentase $89.44 \%$ berarti hasil respons dalam rentangan sangat baik.

Saran untuk pengembangan aplikasi selanjutnya adalah agar ditambahkan hal-hal seperti berikut, (1) Pengembang selanjutnya bisa melanjutkan mebuat game dengan melanjutkan cerita Panji Sakti yang memimpin Desa Den Bukit [14], sampai beliau tutup usia. 2) Pengembang selanjutnya bisa membuat animasi cerita yang lebih menarik pada game saat ini. 3) Pengembang selanjutnya dapat menyuguhkan gameplay yang lebih menarik sehingga pengguna tidak bosan dalam memainkan game. 


\section{DAFTAR PUSTAKA}

[1] J. Schell, The Art of Game Design_ A Book of Lenses. New York: Second Edition-A K Peters_CRC Press, 2014.

[2] T. Dalgleish et al., Game Design Workshop_A Playcentric Approach To Creating Innovative Games, vol. 136, no. 1. United States: Elsevier Inc., 2007.

[3] I. K. D. Permana, "Pengembangan Game Edukasi Siap Selem Berbasis Android," vol. 4, 2015.

[4] A. A. I. Pradnya Uthami, "Pengembangan Game Cerita Rakyat Bali I Bintang Lara Berbasis Android," vol. 7, 2018.

[5] K. Scally, "Theory game: re-examining theory through a game lens," no. July, pp. 0-26, 2015.

[6] C. Crawford, The Art of Computer Game Design. Washington: McGraw-Hill,U.S., 1984.

[7] R. Ramadan, "Game development life cycle guidelines," no. June, 2016.

[8] B. Dinas Kebudayaan, "I Gusti Anglurah Panji Sakti," Sejarah Buleleng, 2000. [Online]. Available: http://www.buleleng.com/psakti1.html. [Accessed: 10-Apr-2018].

[9] S. Dharwiyanti, "Pengantar Unified Modeling Language (UML)," 2003.

[10] N. T. Adi Darma, "Pengembangan Aplikasi Game Kisah Panji Sakti Berbasis Mobile," vol. 6, pp. 283-294, 2017.

[11] P. Rukmi and R. Lakoro, "Perancangan Concept Art Game Berlatar Budaya Majapahit sebagai Media Komunikasi," vol. 1, no. 1, pp. 1-5, 2012.

[12] R. Winarto, "Pengembangan Aplikasi Game Mobile Legenda Selat Bali Manik Multiplatform," Kumpul. Artik. Mhs. Pendidik. Tek. Inform., vol. 7, pp. 1-12, 2018.

[13] I. K. A. M. Wiguna, "Pengembangan Aplikasi Game The Adventure Of Lubdhaka Berbasis Android," Pros. Semin. Nas. Pendidik. Tek. Inform. (SENAPATI 2016), no. Senapati, pp. 1-5, 2016.

[14] K. Kayana, "Sejarah Kerajaan Buleleng," Protein Science, vol. 16, no. 4, Buleleng, pp. 733743, 2007. 